\title{
原著
}

\section{高齢者の咀嚼能力と身体活動性および 生活機能との関連性について}

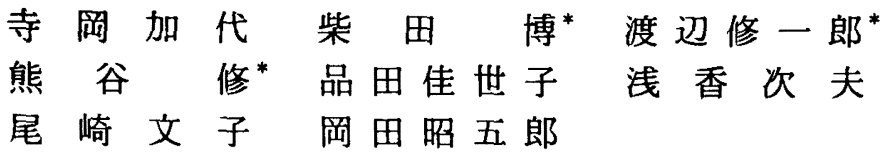

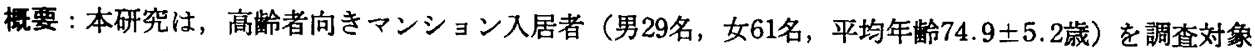

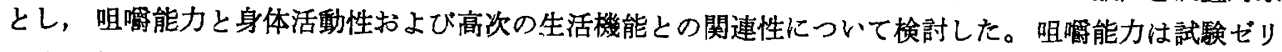
一法と自己評価によって, 身体活動性は敏捷性, 握力および平衡機能, 生活機能は老研式活動能力指標を 用いて評価した。

その結果, 咀嚼能力は身体活動性では敏捷性と握力との間に関連性があり, 生活機能面では「社会的 役割」に属する項目と有意な相関関係が認められた。よって, 高秢者においては咀緭能力が生活の質に 関わる諸因子に影響を及ぼすことが示唆された。
}

索引用語：咀嘌能力, 生活機能, 高齡者

\section{緒 言}

高龄者において咀嚼能力の維持は，身体面では栄義掑 取) 队日常生活動作能力 (Activities of Daily Living; ADL) 2,8) と，また精神面では知的精神活動いわゆる痴 呆2,4) との関連から重視されることが多い。すなわち身 体的あるいは精神的な自立に最低限必要な能力に影響す る因子として注目されている。一方，基本的な生活動作 （食事，入浴，着脱衣など）に関しては自立している 高齢者も多く，そのような人の生活の質（Quality of Life；QOL）を考える場合，低次の身体的自立や知的 機能を維持するだけでは不充分である。したがって，咀 霹能力の QOL への関わりをみるためには，さらに高 次の身体活動や生活機能を取りあげ，咀嚼能力とそれら の因子との関連性を検討する必要がある。

本研究は, 60歳以上の高齢者向きマンション入居者の 咀嚼能力の実態を把握するとともに，咀嚼能力と $Q O L$ に影響する身体活動および生活機能との 関連性を 検郡
し, 高齢者における咀虂能力維持の新たな側面を探るこ とを目的とする。

\section{対象および方法}

埼玉県下の身体的にも精神的にも自立していることが 入居条件である高龄者向きマンションの入居者(男29名， 女61名，平均年齢 $74.9 \pm 5.2$ 歳）を調査対象とした。

\section{1. 口腔内状況の調查}

口腔内診査により，対象者を次の 3 群に分けた。

1）疎失歯10歯以下で，全く補経のなされていない者

2）部分床義歯を装着している者

3）全部床義歯を装着している者

2. 咀噮能力の評価

1）客観的評価（G-1ゼリーによる）

G-1ゼリー5)（No. 3 と No. 5) を用い, 石山らの方 法6) に従って, 咀嚼能力の評価を行った。その評価にも とゔいて，対象者を以下の 3 群に分けた。

I 群；No. 5のゼりーを口の中に入れ，10回咀嚼させ

東京医科齿科大学媇学部予防歯科学講座（主任：岡田昭五郎）

* 東京都老人総合研究所地域保健部門

受付: 平成 6 年 6 月 12 日, 受理 : 平成 6 年 8 月 17 日 
654

\section{大きさが $1 / 2$ 以下になる者}

II群 : No. 5のゼリーの大きさが $1 / 2$ 以下にならず, No. 3のゼリーの大きさが1/2以下になる者

III群; 10回咀螎後, No. 3のゼリーの大きさが $1 / 2$ 以下 にならない者

2）主観的評価（自己評価による）

咀繒状態を次の 3 段階に分け，自己評価した結果を閔 き取り調査した。

1. どんなものでも欲しいものを噌んで食べられる。

2. 圖みにくいものもあるが大低のものは食べられ る。

3.あまり㗪めないので食べ物が限られている。

3. 身体活動測定

1）棒落下テスト》

このテストは落下する棒を敏捷に握るテストである。 先ず，被検者には利き手の拇指々第 2 指を軽く開かせ， その間を落下する棒が握れるよう準備させる。検者は木 製の棒（長さ $50 \mathrm{~cm}$, 直径 $2.3 \mathrm{~cm}$, 重さ約 $100 \mathrm{~g}$ ）の最下端 が第 1 指の最上端に一致するようにつり下げる。被検者 は棒が落下しはじめたら，できるだけ早くその棒を握 る。握った棒の第 1 指の上端から棒の最下端までの長さ を読み取る。 5 回施行して, 最高, 最低値を除いた $3 っ$ の值の平均值を棒落下テストの結果とした。

2) 握力の測定 ${ }^{7)}$

Smedley 式握力計を使用し，被検者の利き腕の最大 握力を1回測定した。

3） 開眼片足立ち時間の測定 ${ }^{8)}$

開眼状態で直立し，立位保持時間を測定した。

\section{4. 生活機能の評価}

生活機能の自立性を評価するため, 老研式活動能力指 標㳫を用い，閚き取り調查を行った。

\section{5. 統計学的検討}

カイ 2 乗検定㧍よび一元配置分散分析により統計学的 有意性を検討し， $\mathrm{p}<0.05$ 以上を有意と判定した。

\section{結果}

1. 性, 年齢と G-1 ゼリーによる咀嚼能力との関連 性

Table 1 に性，年齢と G-1ゼリーによる咀嚼能力との 関連を示す。

1) 性

性別に咀嚼能力をみると, 男性では，I 群； $69.0 \%$, II 群；20.7\%，四群；10.3\%で，女性ではそれぞれ 67.2 $\%, 23.0 \%, 9.8 \%$ であり，男女により有意な差異はみら
Table 1 Sex, age and masticatory ability measured objectively

\begin{tabular}{|c|c|c|c|c|c|}
\hline & & & Masticat & ry ability & roup (\%) \\
\hline & Cate & & Group I & Group II & Group III \\
\hline Sex & Male & (29) & 69.0 & 20.7 & 10.3 \\
\hline & Female & (61) & 67.2 & 23.0 & 9.8 \\
\hline Age & $160-69$ & (17) & 64.7 & 29.4 & 5.9 \\
\hline & $270-79$ & (58) & 70.7 & 19.0 & 10.3 \\
\hline & $380-$ & (15) & 60.0 & 26.7 & 13.3 \\
\hline
\end{tabular}

Table 2 Oral condition and sex

\begin{tabular}{lrc}
\hline & Male (n) & Female (n) \\
\hline 1. $\begin{array}{l}\text { Number of missing } \\
\text { teeth below 10 }\end{array}$ & 5 & 11 \\
$\quad$ (no denture) & & \\
2. Partial denture & 21 & 42 \\
3. Complete denture & 8 & 3 \\
\hline
\end{tabular}

れなかった。

2) 年齢

年齢を 60-69歳，70-79歳，80歳以上の 3 群に分け，咀 嚼能力との関連をみた結果, 年齢による咀獣能力の分布 に有意な差はなかった。

2. 口腥内状況と G-1 ゼリーによる咀喓能力との関 連性

口腔内診查の結果を Table 2 に示す。無歯嶺者を含 め, 岥失歯11歯以上で全く補緅のなされていない者はい なかった。

口腔内状況と G-1ゼリーによる咀嚼能力（客観的評 価）との関連性を Fig. 1 に示す。䘫失歯10歯以下の者 は全て I 群となり, 部分床義菊装着者は I 群 8 名, II 群 50 名, III群 5 名, 全部床義㐘荘着者は I 群はなし, II 群 3 名, III群 8 名であった。

3. G-1 ゼリーによる咀嚼能力と自己評価による咀瞵 能カとの関連性

咀筑能力評価の結果は, I 群 (No. 5 可能); 男20名, 女41名, II群 (No. 3 可能); 男 6 名, 女14名, III群 (No. 3 不可能)；男 3 名，女6名であった。

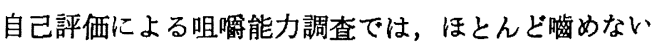
者や，全く啮めず流動食を食べている者はいなかった。 ゼリーテストのI 群, II 群, II群の順に自己評価によ る咀哷能力む低下し, 両者の間には有意な関連性が認め られた $(\mathrm{p}=0.000003$ ) (Fig. 2)。 


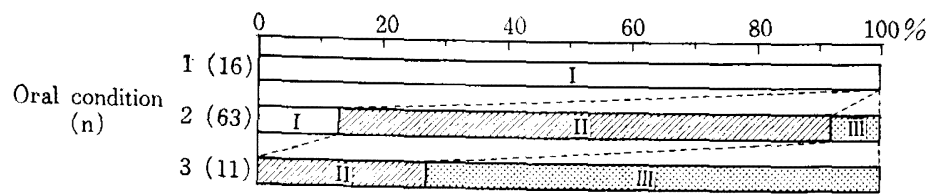

Oral condition 2: Partial denture

1: Number of missing teeth below 10 (no denture)

3 : Complete denture

Masticatory ability group I : Group that could chew No. 5 jelly

measured objectively II : Group that could chew No. 3 jelly

III : Group that could not chew No. 3 jelly

Fig. 1 Oral condition and masticatory ability measured objectively

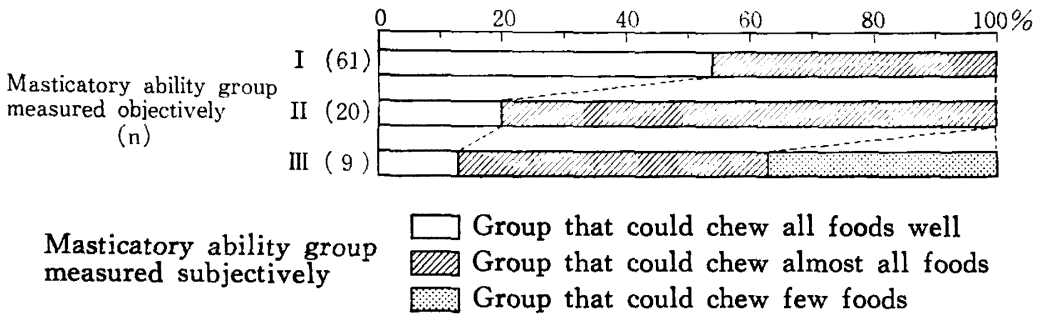

Fig. 2 Masticatory ability measured objectively and subjectively

Table 3 Physical activities and masticatory ability

\begin{tabular}{ccr}
\hline Physical activities & $\begin{array}{l}\text { Masticatory } \\
\text { ability }\end{array}$ & Mean \pm S.D. \\
\hline Quickness & Group I & $24.2 \pm 5.7$ \\
(cm) & Group II & $26.5 \pm 7.9$ \\
& Group II & $29.4 \pm 8.3$ \\
Grip strength & Group I & $3.1 \pm 7.2$ \\
(kg) & Group II & $21.0 \pm 6.3$ \\
& Group III & $17.3 \pm 3.7$ \\
Equilibrium & Group I & $27.1 \pm 22.1$ \\
(sec) & Group II & $22.7 \pm 19.4$ \\
& Group III & $19.2 \pm 20.7$ \\
\hline
\end{tabular}

\section{4. 身体活動測定}

開眼片足立ち時間を測定した結果, 咀嚼能力群間で差 は認められなかったが, 棒落下テストおよび握力測定で は, I 群, II 群, 皿群の順に, 棒落下の距離は長く（p= 0.061), 握力は小さくなる $(\mathrm{p}=0.056)$ 傾向がみられた (Table 3)。

\section{5. 生活機能の評価}

全般的に生活機能の自立度は高く，「はい」と答える 者が多かったが，項目10，11，12では牦群で「いいえ」

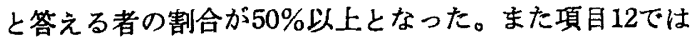

$5 \%$ の有意水準で咀緭能力群間で差が認められた（Table 4)。

\section{考察}

咀嘌能力が食生活に影響することは自明のことである が，高齢者の場合はその影響が生活の活動範囲にまでお よぶことが報告10)されている。老年期の QOL について は，身体的な 加龄変化は不可避的な 事実であることか ら，精神的・社会的自立がいかに維持されているかが重 要な劺を握ると考えられる。さらに両者の自立によっ て, 生活の活動範囲も広がることになる。したがって, 食のあり様に影響する咀礵能力は, 高龄者の QOL を規 定する因子とも梁く関わっていることが予想される。そ こで，今回の調查では ADL の自立よりさらに高次の 活動のために必要であると考えられる身体的因子ならび に精神・社会的因子を取りあげ，咀嚼能力との関連性に ついて検討した。調查対象者は, 高齢者向きマンション の入居者であることから，ADL は自立しており，知的 精神機能む正常である。

咀嚼能力に関しては，G-1ゼリーによる客観的評価と 自己評価による主観的評価との間に非常に高い相関関倸 が認められ，No. 3ゼリーが咀嗳可能な者は，自覚的に も大低のものが食べられるょうであった。 
Table 4 The percentage of positive replies to the TMIG Index of Competence

\begin{tabular}{|c|c|c|c|c|}
\hline & & I 群(61) & II 群 (20) & III群 (9) \\
\hline (1) & バスや電車を使ってひとりで外出できますか & $91.7 \%$ & $100.0 \%$ & $85.7 \%$ \\
\hline ( 2 ) & 日用品の買い物ができますか & 100.0 & 100.0 & 100.0 \\
\hline (3) & 自分で食事の用意ができますか & 89.6 & 100.0 & 87.5 \\
\hline (4) & 請求書の支払いができますか & 95.8 & 100.0 & 100.0 \\
\hline (5) & 銀行預金・郵便貯金の出し入れが自分でできますか & 97.9 & 100.0 & 100.0 \\
\hline (6) & 年金などの書類が書けますか & 97.8 & 100.0 & 100.0 \\
\hline (7) & 新開を読んでいますか & 93.8 & 93.3 & 75.0 \\
\hline (8) & 本や䧴誌を読んでいますか & 85.4 & 86.7 & 75.0 \\
\hline (9) & 健康についての記事や番組に関心がありますか & 93.8 & 80.0 & 87.5 \\
\hline (10) & 友達の家を葹ねることがありますか & 64.6 & 60.0 & 37.5 \\
\hline (11) & 家族や友達の相㪍にのることがありますか & 73.9 & 57.1 & 50.0 \\
\hline (12) & 病人を見舞うことができますか & 87.5 & 78.6 & 50.0 \\
\hline (13) & 若い人に自分から話しかけることがあります & 75.0 & 60.0 & 75.0 \\
\hline
\end{tabular}

$*: \mathrm{p}<0.05$

咀獣能力と身体活動との関連性をみた結果，咀嚼能力 の高い群ほど握力は大きくなる傾向が認められ，これは 著者らが以前特別養護老人ホームで行った調查 ${ }^{3)}$ の結果 と一致した。また棒落下テストは敏捷性を評価する目的 で行ったが，咀嚼能力が高い群ほど棒落下距離は短い， すなわち敏捷性は高くなる傾向が認められた。握力は簡 便に高龄者の身体活動全般を推測する指標であることか ら，握力の大きい咀撆能力群では他の身体活動性も高、 ことが予想されたが，今回の調査で敏捷性も高くなる傾 向が明らかとなった。開眼片足立ち時間は姿勢調節能力 をみることによって，平衡機能を評価する指標となる。 平衡機能は歯牙の咬合状態，すなわち上下蝢の位置関係 に影響される ${ }^{11}$ が，本調查の対象者は口腔内診査の結 果，歯牙欠損部位には補緅処置（橋義歯，義歯）がなさ

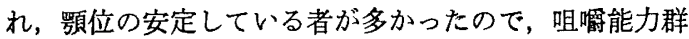
間による平衡機能には差が認められなかったと考えられ る。

老研式活動能力指標9) は，基本的な生活動作の自立し た高齢者が，独立した張りのある生活を維持するために 必要な生活機能を評価することを目的として，東京都老 人総合研究所のグループによって 開発された 尺度であ る。各質問項目のうち, 項目 1-5 は「手段的自立」, 項目 6-9 は「知的能動性」, 項目10-13は「社会的役割」に関 するものである。対象者の特性から，全般的に自立度は 高かったが，3つのカテゴリーの中では，「社会的役割」 において咀嚼能力の低い群, すなわち，食べられる物に
制限のある而群で、「いいえ」と答える者が多くなった。 「社会的役割」の項は，人との関わりに深く関係する。 咀緭能力低下のため食べられない物があるということ は，人と同じ物が食べられない，食へるのに時間がかか る等の理由で，他人と食事を共にすることへの障害とな り，人とのつき合いの面でマイナス要因となる。一般的 に社会との熬がりが 希薄化する 高齢者にとって,「人」 や「社会」との関係は心身の健康に大きく影響し，両者 との熬がりを少なからず左右する咀礵能力の問題は， QOL にも関わる重要な意味を持つと考えられる。

従来上り咀嚼能力維持の重要性は, 身体的にも精神的 にも基本的自立の観点から捉えられてきたが，今回の調 查結果から高齢者の QOL に大きく影響する高次の自立 に関わる因子との関連性が示唆された。

\section{結 論}

高齢者において「生活の質」(QOL) を維持するため には，身体的にも精神的にも基本的な自立のみならず，。 さらに高次機能の自立を必要とする。今回高齢者向きマ ンション入居者を対象とし，QOL に関わる生活諸因子 を取りあげ咀噮能力との関係を調査した結果, 身体活動 性では敏捷性および握力, 生活機能の面では「社会的役 割」との関連性が示唆された。

\section{謝 辞}

稿を終えるにあたり，本調查の遂行に御協力を頂いた 
高龄者向きマンション“センチュリーシティ大宫公園”

の入居者ならびに株式会社センチュリーシティライフの スタッフに皆様に心より感謝いたします。

\section{文献}

1）東京都老人総合研究所, プロジェクト研觉：秋 田県南外村老人健康調查，63；58-64，1989.

2) 平井敏博, 田中収, 池田和博, 矢島俊彦, 富田喜内：高齢者の咀嚼機能と精神活動, 口科 誌, $37 ; 562-570,1988$.

3）寺岡加代, 永井晴美, 柴田 博, 岡田昭和郎, 竹内孝仁：高齡者に打ける提食機能の身体活動 への影響，口衛誌，42；2-6，1992.

4) 沖本公絵, 家入浩二, 松尾浩一, 寺田善博; 老 化と咀嗗——老人病院における口腔の実態と痴 呆度との関連性について, 補棨誌, 35 ; 91-94, 1991.

5) 湖山昌男, 石山直欣, 渡辺郁馬, 佐藤亭, 腰 原 好，牧野正義：ゼリー（G-1 ゼリー）を用 いた咀霞能力判定試料に関する研究, 老年学, 6 ; 126-131, 1992.

6) 石山直欣, 平野活彦, 笠原諏訪子, 渡辺郁馬,
山根 睡, 牧野正義: 地域老年者の咀嚼能力お よび口腔内状況に関する研究，第 1 報, 口腔内 調查のフレームワークについて, 老年歯学, $7 ; 1000-1005,1993$.

7）文部省体育局編：昭和56年度体力, 運動能力調 查報告書. 28-41, 1992.

8）日本平衝神経科学会編：平衡機能検査の手引き, 南山堂, 50-65, 1981.

9）古谷野亘, 柴田 博, 中里克治, 芳賀 博, 須 山靖男: 地城における活動能力の測定一老研式 活動能力指標の開発, 日公衛誌, 34; 109-114, 1987.

10）新庄文明, 岩崎さとみ, 安積宗：歯者保健セ ンターを基盤にした南光町における成人歯科保 健事業, 日本歯科評論, $530 ； 170-175 ， 1986$.

11）伊藤吉美監修：口腔内科学; 第 1 版, 永末書店, $372,1985$. 


\title{
Relationship between Masticatory Ability and Physical
} Activity and Competence in the Elderly

\author{
Kayo TERAOKA, Hiroshi SHIBATA*, Shuichiro WATANABE*,
} Shu KUMAGAI*, Kayoko SHINADA, Tugio ASAKA, Fumiko OZAKI and Shogoro OKADA

Department of Preventive Dentistry, Tokyo Medical and Dental University, School of Dentistry (Director : Prof. Shogoro OKADA)

* Department of Community Health. Tokyo Metropolitan Institute of Gerontology

Journal of Dental Health 44, 653-658 (1994)

\begin{abstract}
The aim of the present study was to elucidate the role of masticatory ability in maintaining the quality of life in the elderly.

Masticatory ability was evaluated by the test jelly method and self-assessment. The life-related factors assessed were grip strength, quickness and equilibrium as physical activities, and the TMIG Index of Competence that was designed to measure Instrumental Self-maintenance, Intellectual Competence and Social Role as high-level competence.

The results were the following.

1) The group who kept their masticatory ability also retained grip strength and quickness. Regarding equilibrium, there was no relation to masticatory ability; this might be due to the fact that most subjects in this study had the stable mandibular position because of prosthetic treatments.

2) Keeping the masticatory ability was related to performing Social Role in the TMIG Index of Competence. This result might indicate that masticatory ability takes part in maintaining the social contacts which affect mental and physical health of the elderly.
\end{abstract}

Koy words: Masticatory ability, Quality of life, Elderly persons 